\title{
MACRO-AND MICROMORPHOLOGY OF THE LEAVES, STEM AND ROOT OF CENTAUREA ERYNGIOIDES LAF.
}

T.M. Sarg, M.M. El-Domiaty, S.I. El-Dahmy, A.M. A teya and A.M. El-Shazly

Department of Pharmacognosy, Faculty of Pharmacy, University of Zagazig. Egypt.

ABSTRACT :

The macro-and micromorphology of the leaves, stem and root of Centaurea eryngioides are presented with the aim of finding out the characters of these organs by which the plant could be identified, characterized and differentiated from other species, both in the entire and powdered forms.

\section{INTRODUCTION}

Centaurea eryngioides Lam. (Family Compositae) is a persennial Egyptian plant growing wildly in Saint Catherine, Sinai(1). Many Centaurea species are currently used in folk medicine as diuretic, astringent, stomachic, bitter and digestive(2). Some of these species shows antihypertensive, hypoglycaemic ${ }^{(3)}$, cytotoxic and/or antitumor activities ${ }^{(4)}$.

In previous publications, we reported the isolation and characterization of four sesquiterpene lactones ${ }^{(5)}$, five flavonoids and five steroidal compounds ${ }^{(6)}$. Nothing was reported in the literature about macro-and micromorphology of the plant except few data given by some flora ${ }^{(1)}$.

IN the present work, we are fealing with the macro-and micromorphology of the leaves, stem and root of the plant.

\section{EXPERIMENTAL}

Fresh samples cf Centaurea eryngioides Lam. used in
this work was collected from Saint Catherine, Sinai, 


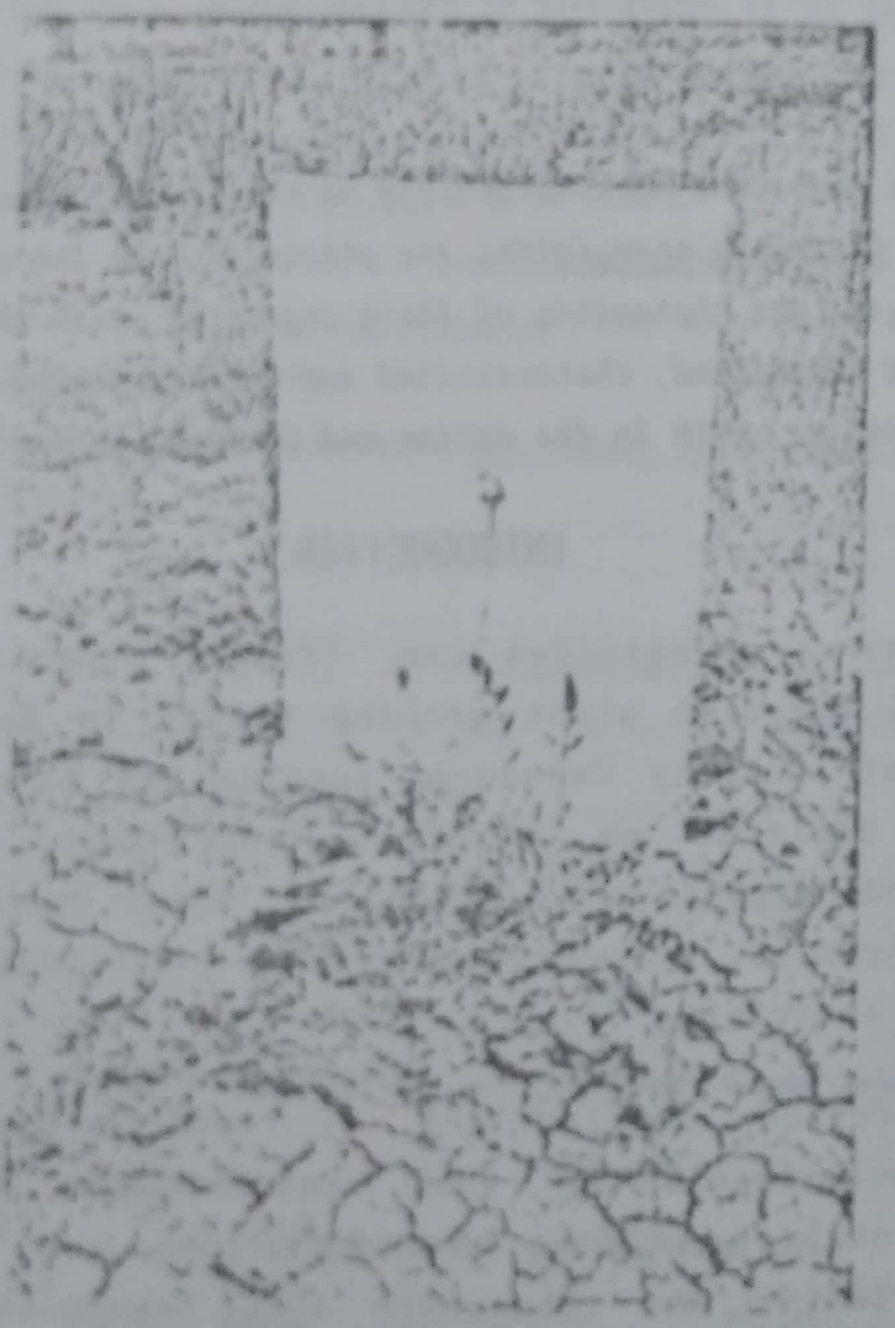

(Pig. 1) i A Photograph of Centaurea eryngtoldes Las, $(x 0.14)$ 
Egypt, in April 1986 and May 1987. Identification of the plant was kindly verified by Dr. N. El-Hadidi Prof. of Plant Taxonomy, Cairo University.

\section{A - MACROMORPHOLOGY :}

Centaurea eryngioides Lam. (Fig. 1 \& 2) is a perennial, erect, branched hairy herb attaining $50 \mathrm{~cm}$. in height with rosette of $7-12$ radical leaves and small cauline ones. The plant has green cylindrical stem carring few terminal and axillary large rose red capitual, with an involucre scale showing white fringes and terminal long, yellow spines. It floweres from March to May.

The leaf : (Fig, 2)

The leaves include a rosette of $7-12$ radical leaves as well as two types of cauline leaves. They are simple, sessile, exstipulate with green and hairy surfaces. The leaves have pinnately reticulate venation. The radical and lower cauline leaves (Fig. 2C \& E) are oval lanceolate to linear spathulate deeply pinnatisect, acute apices and ent ire margins. The upper cauline leaves (Fig. 2D) are alternate, small, ovate-lanceolate, having entire margin, hairy surfaces and acute apices. It measure $3-10 \mathrm{~cm}$. in length and $0.6-1.0 \mathrm{~cm}$. in broad. The lower cauline measure $6-10 \mathrm{~cm}$ in length and $0.6-0.9 \mathrm{~cm}$ in breadth. The radical leaves measure $13-20 \mathrm{~cm}$ in length and $0.7-1.6 \mathrm{~cm}$ in broad. The leaf has a slight odour and a slight bitter taste.

\section{The Stem : (Fig. 2)}

It is erect, nerbaceous, cylindrical, solid with glabrous green ridged surface; showing 6-8 ridges. The stem shows alternate monopodial branching and long inter- 
Sarg et al

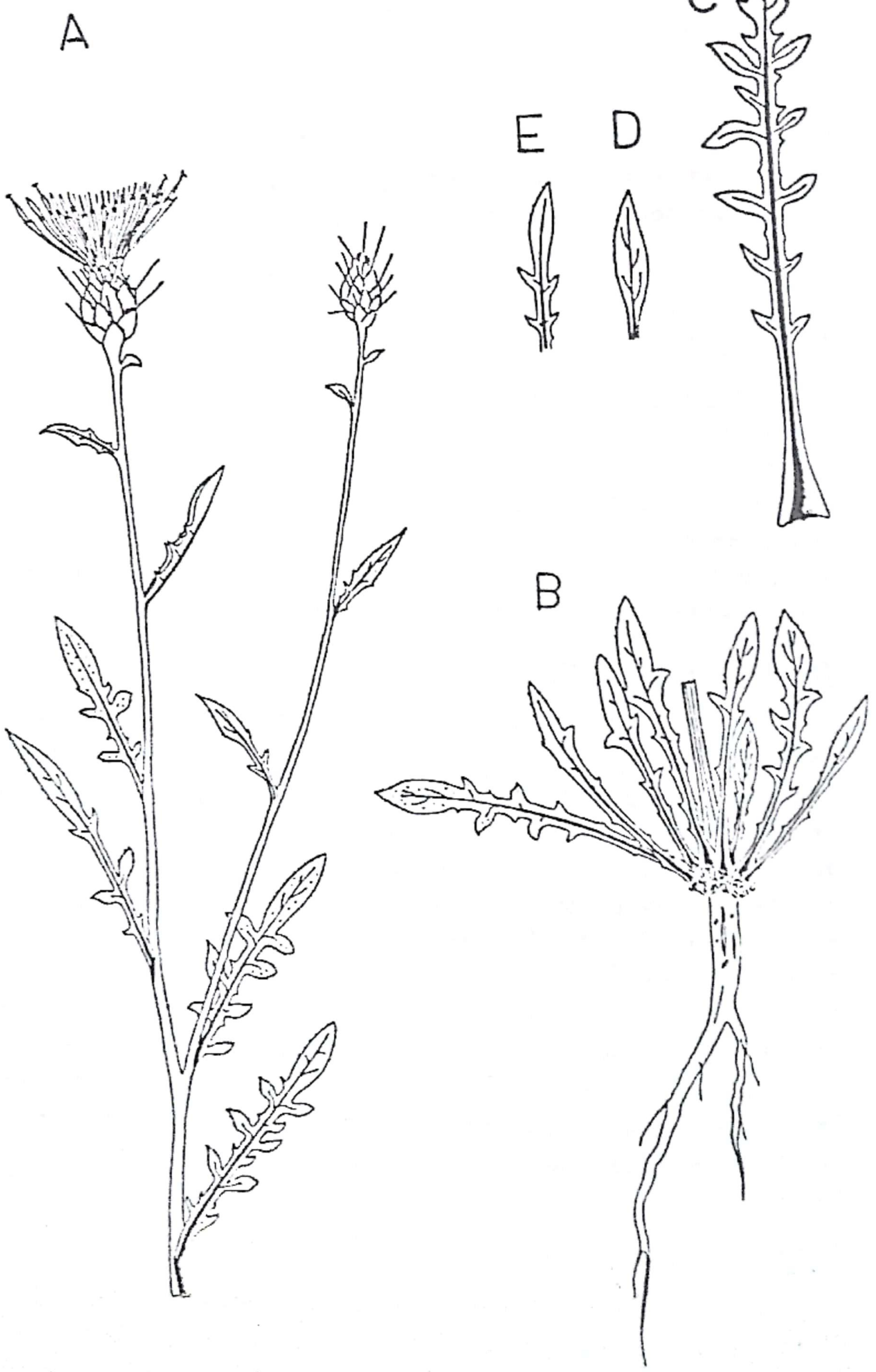

(Fig. 2) : Sketch of Centaurea eryngioides Lam. (All $\times$ 0.5)
A. The stem and cappituluen.
13. The wast and fathich teates.
C. Intical teap.
D. Uater caution leaf
f. Lower cauline leat. 
nodes reaching up to $12 \mathrm{~cm}$. in length. The stem measures 20-50 in length and $0.5-1.0 \mathrm{~cm}$ in diameter. The fresh stem is flexible, while dry one breaks with fibrous fracture. The stem has slight ldour and slight bitter taste.

The Root : (Fig. 2B)

The plant possesses a terete gap root, bearing few lateral roots and numerous rootlets. Externaliy, it is earthy brown in colour with rough longitudnally wrinkled surface. The root measure 15-29 cm. in length and 0.5-1.5 $\mathrm{cm}$. in diameter at the widest part. It has fibrous fracture showing yellow interior. The root has sight odour anc slight salty taste.

\section{B - MICROMORPHOLOGY :}

\section{The Leaf :}

The transverse section of the leaf (Fig. 3 A,B) shows and isobilateral structure, palisade being discontinuous in the region of the midrib. The midrib is more prominent on the lower surface showing three collateral vascular bundles, each consists of radiated xylem and phloem with an upper and a lower arcs of pericyclic fibres.

Epidermis : the epidermal cells of both upper and lower surfaces (Fig. 4A,B,C,D) are polygonal with slightly wavy anticlinal walls being, more wavy in the lower one and are covered with smooth cuticle. The neural epidermal cells are subrectangular and axially elongated with straight anticlinal walls. The cell dimensions are shown in table (1). 

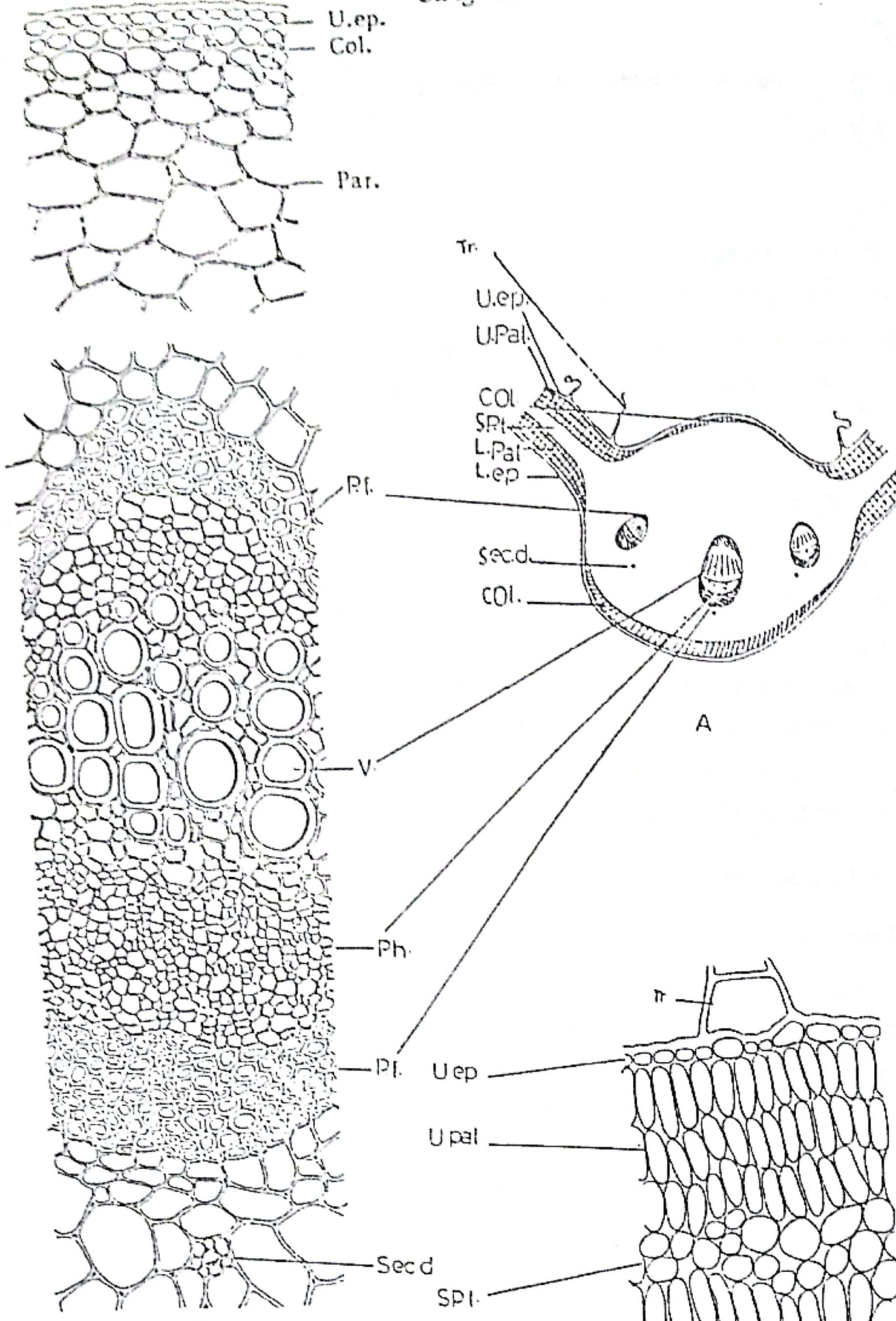
Table (1) : Epidermal Cell Size of the Leaf (in micron).

\begin{tabular}{lrrr}
\hline Region of Epidermis & Length & Width & Height \\
\hline Upper epidermis of the lamina & $28-68$ & $17-53$ & $10-21$ \\
Lower epidermis of the lamina & $28-72$ & $20-43$ & $7-13$ \\
Upper neural epidermis & $34-96$ & $11-26$ & $9-14$ \\
Lower neural epidermis & $40-91$ & $7-28$ & $7-16$ \\
\hline
\end{tabular}

Stomata : (Fig. 4A,B,C); They are slightly sunken, oval, anomocytic, occasionally anisocytic present on both surfaces, being more numerous on the lower. They measure $32-34 u$ in length and $23-25 u$ in width.

Trichomes : (Fig. 4E); They are of the covering type only and present mostly on the upper surface and the margin of the leaf. They are uniseriate, multicallular $(6-13$ cells), covered with smooth cuticle and ending with a long slender whip-like terminal cell, few having occasionally collapsed cell. They measure 749-1000 $u$ in length and 65-82 $u$ in width. At the basal part of the radical leaves, there are numerous narrow, uniseriate multicellular covering trichomes measuring 795-1022 $u$ in length and 8-9 u in width, having narrow apical cells with acute apices.

Mesophyll : (Fig. 3B)

The mesophyll consists of an upper and a lower palisade eac of 3 rows of short columar cells, measuring 40-102 $u$ in length and 15-32 $u$ in breadth as well as a spongy tissue formed of 3 fows of rounded parenchymatous cells.

Midrib :

Cortical tissue (Fig. 3B); is formed of thinwalled parenchyma with 1 to 4 rows of subepidermal collenchyma. Few small schizogencus ducts are found in the cortex. 
The endodermis : It is not well differentiated.

Pericycle : the pericycle consists of two ares of lignified fibres above and below each vascular bundle. The fibres (Fig. 4F); are spindle-Shaped, with thick lignified pitted walls, narrow lumin and pointed ends. They measure $176-270 \mathrm{u}$ in length and $17-20 \mathrm{u}$ in diameter.

The vascular tissue : (Fig. 4F); consists of a central and two lateral vascular bundles, each consists of upper lignified radiating $x y l e m$ and lower soft parenchymatous phloem elements. The xylem is formed of lignified spiral, annular and reticulate vessels measuring 13-28 u in diameter, separated by thin cellulosic wood parenchyma.

The numerical values of the leaf are listed in table (2).

Table (2) : Numerical values of the leaf.

Values

1. Stomatal index :

a) The upper epidermis

$18-25$

b) The lower epidermis $20-28$

2- Vein islet number

3- Vein termination number

$11-14$

4- Palisade ratio:

a) Upper

b) Lower

$$
2-3
$$

\section{The Stem:}

A transverse section of the stem (Fig. $5 \mathrm{~A}, \mathrm{~B}$ ); is almost circular in outline with 6-8 slightly prominent ridges. It shows an outer epidermis followed by a narrow 
Zag. J. Pharm. Sci., Vol. 1, No. (1-2), Nov. 1992
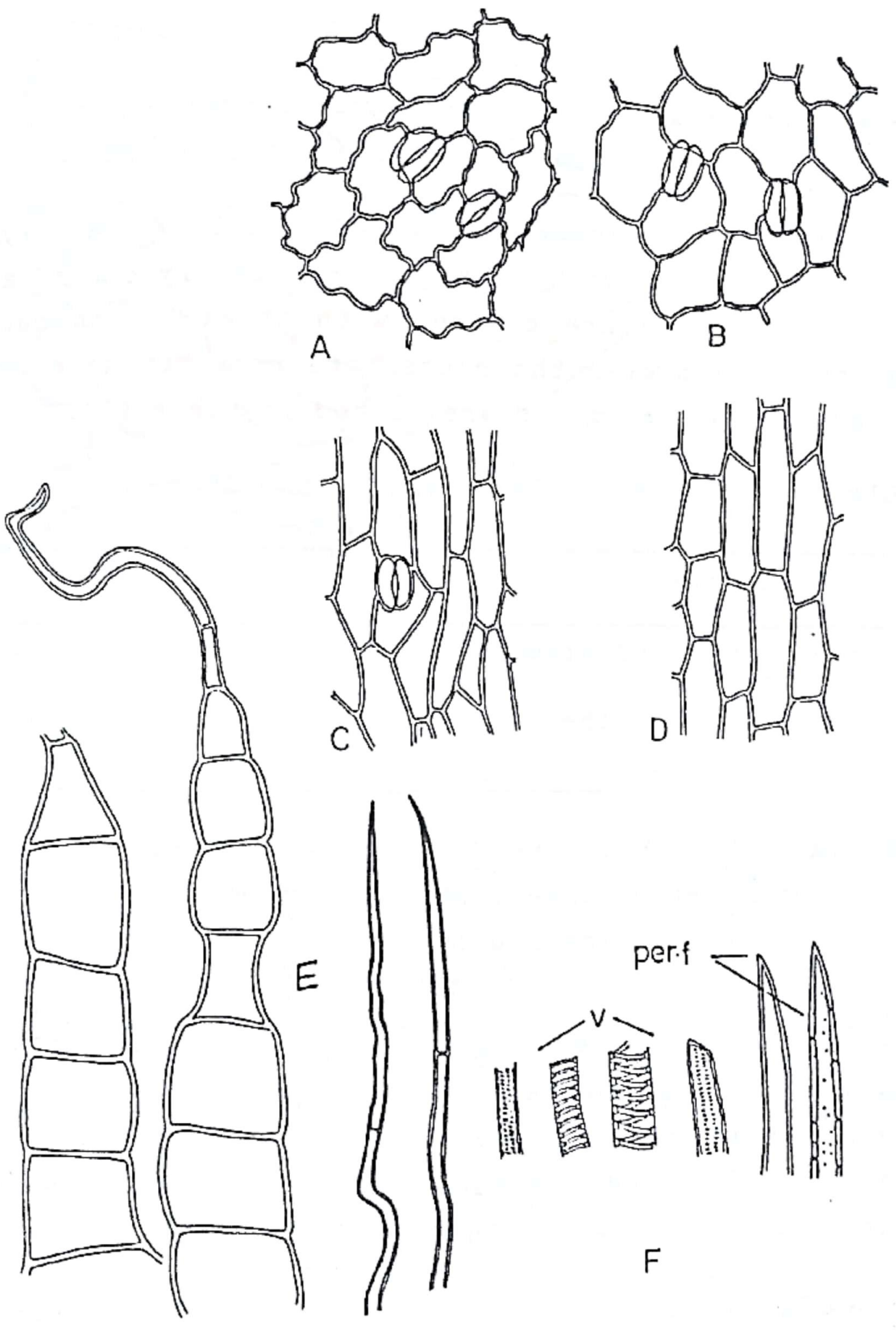

(Fig. 4): The leat: (All $\times 330)$

A. Lower epidetmal cells of the lamina.

1). Upper epidermal cells of the midrib.

B. Upper epidermal cells of the lamino.

E. Trichomes of the leat.

C. Lower epidermal cells of the midrib.

F. Isolated elements from the leat.

Per, r., Pericycilc tiber; V., vessels. 
cortex, lined with endodermis enclosing a ring of 13-18 vascular bundles surounding a wide lignified pith.

Epidermis : The epidermal cells (Fig. 6C,E); are polygonal axially elongated with straight or slightly curved anticlinal walls and are covered with thick smooth cuticle. Epidermal cells over the ridges are somewhat narrower and longer. Cells dimensions are listed in table (3).

Table (3) : Epidermal Cell Size of the Stem. (in micron).

\begin{tabular}{ccc}
\hline Epidermis & Length & Width \\
\hline Epidermal cell of stem. & $23-65$ & $11-34$ \\
Epidermal cell on the ridges & $85-106$ & $14-23$ \\
\hline
\end{tabular}

Stomata : (Eig. 6E); are few of the anomocytic and anisocytic types being sunken, absent over ridges and measuring $22-31 u$ in length 18-22 $u$ in breadth.

Trichomes : ( Figure $6 \mathrm{C}_{2}$ ), few, covering trichomes are present being uniseriate, multicellular 5-10 cells and covered with thin smooth cuticle. The apical cell is small with pointed and curved apex. They measure 170-210 $u$ in length and $10-18 \mathrm{u}$ in breadth.

Cortex : (Fig. 5B ), is formed of $8-15$ rows of thin walled parenchyma cells, four to six rows of collenchyma in the ridges with scattered single or groups of lignified thick-walled sclereids. The cortex is lined its inner side by tangentially elongated small endodermal cells, free of any contents. The cortex shows $5-7$ small schizogenous secretory ducts. 
Zag. J. Pharm. Sci., Vol. 1, No. (1-2), Nov. 1992

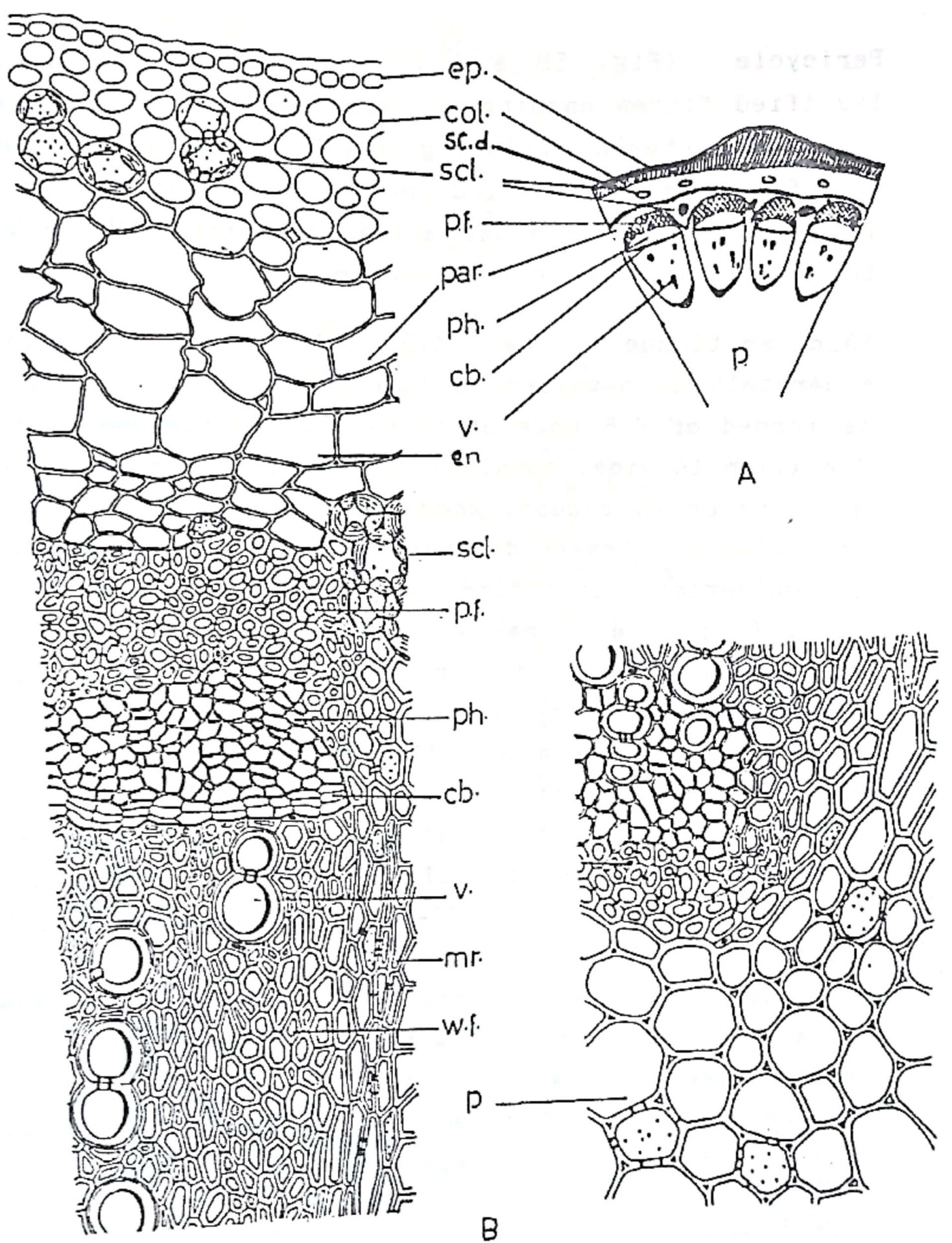

(rig. 5) : The stem : (All $\times 246.4$ except $B \times 22.4)$

A. Diagrammatic transverse Section of stem. B. Detailed transverse Section of the stem. Cb., cambium; Col., Collenchyma; ep., epidermis; m.t., mociullary ray; par., patenchyma; P.f. perticyclic fiber; Ph., phioem; P. pith; Sch., scleride; Sc.d. secretary ducts; V., ressel; W.t., wool fibet. 
Pericycle (Fig. 5B \& 6D); is composed of groups of lignified fibres capping the vascular bundles and parenchyma in between including small groups of sclereids. The fibres are lignified and spindle-shaped with wide lumina and blunt or acute apices measuring 375 to 610 u in length and 17-22 $u$ in diameter.

Vascular tissue : (Fig. 5A,B ); The phloem; consists of moderately thin-walled cellulosic elements. The cambium is formed of 2-5 rows of thin-walled meristematic cells. The xylem is wide, consists of lignified vessels arranged solitary or in groups, wood fibres, wood parenchyma, few tracheids and tracheidal vessels. The xylem is traversed by uniseriate lignified medullary rays. The vessels (Fig. 6D); have spiral and annular thickening, 12-19 u in diameter. The wood fibres have thick lignified pitted 395-698 u in length and 11-17 upices, they measure parenchyma is formed of lignified in diameter. The wood walls. The vascular bundle ared cells with thick pitted tiseriate lignified medule are separated by wide mul$77-93 u$ in length and $23-37$ rays. The cells measure sclerenchyma formed of $4-10$ cells in breadth. A band of periphery of medullary rays. The caps is located in the less rounded, lignified with the sclereids are more or pits, they measure 48-93 u fine striation and simple breadth. The pith is composed of length and $36-48 \mathrm{u}$ in large pitted parenchymatous cells. The Root : A transverse section of the root (Fig. $7 \mathrm{~A}, \mathrm{~B}$ ); shows
an outer brown cork and parenchymatous phelliderm sur-
rounding a wide vascular cylinder traversed by medullary
rays. The cork (Fig. $7 \mathrm{~B}, \mathrm{C}$ ); consists of about $3-6$ layers
of polygonal thin-walled suberised tangentially elongated A transverse section of the root (Fig. $7 \mathrm{~A}, \mathrm{~B}$ ); shows
an outer brown cork and parenchymatous phelliderm sur-
rounding a wide vascular cylinder traversed by medullary
rays. The cork (Fig. $7 \mathrm{~B}, \mathrm{C}$ ); consists of about $3-6$ layers
of polygonal thin-walled suberised tangentially elongated A transverse section of the root ( $F$ ig. $7 \mathrm{~A}, \mathrm{~B}$ ); shows
an outer brown cork and parenchymatous phelliderm sur-
rounding a wide vascular cylinder traversed by medullary
rays. The cork (Fig. $7 \mathrm{~B}, \mathrm{C}$ ); consists of about $3-6$ layers
of polygonal thin-walled suberised tangentially elongated A transverse section of the root (Fig. $7 \mathrm{~A}, \mathrm{~B}$ ); shows
an outer brown cork and parenchymatous phelliderm sur-
rounding a wide vascular cylinder traversed by medullary
rays. The cork (Fig. $7 \mathrm{~B}, \mathrm{C}$ ); consists of about $3-6$ layers
of polygonal thin-walled suberised tangentially elongated 
Zag. J. Pharm. Sci., Vol. 1, No. (1-2), Nov. 1992

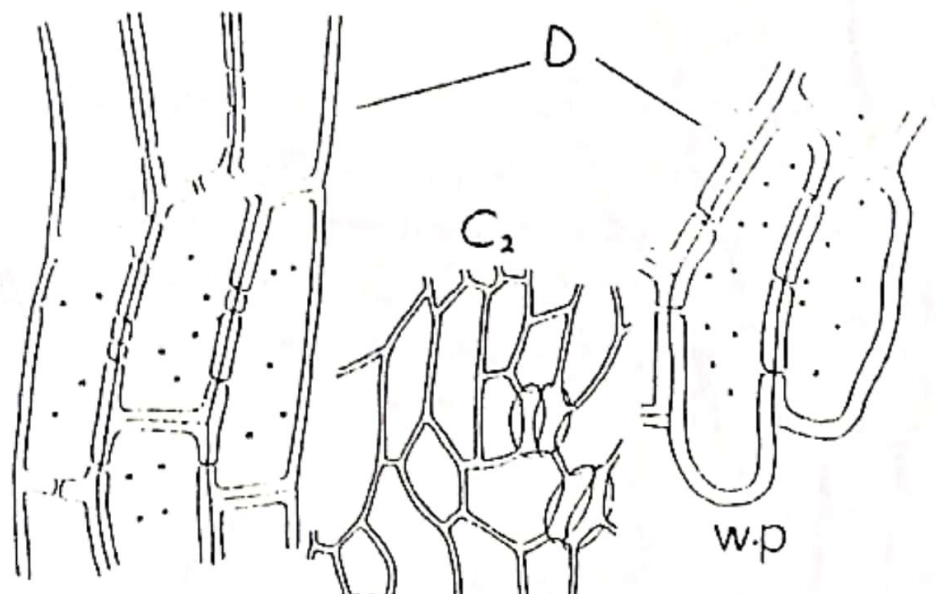

m.r.
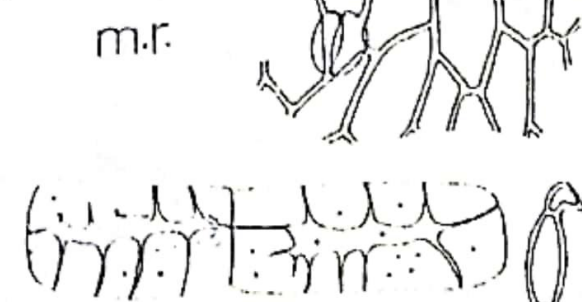
scl.
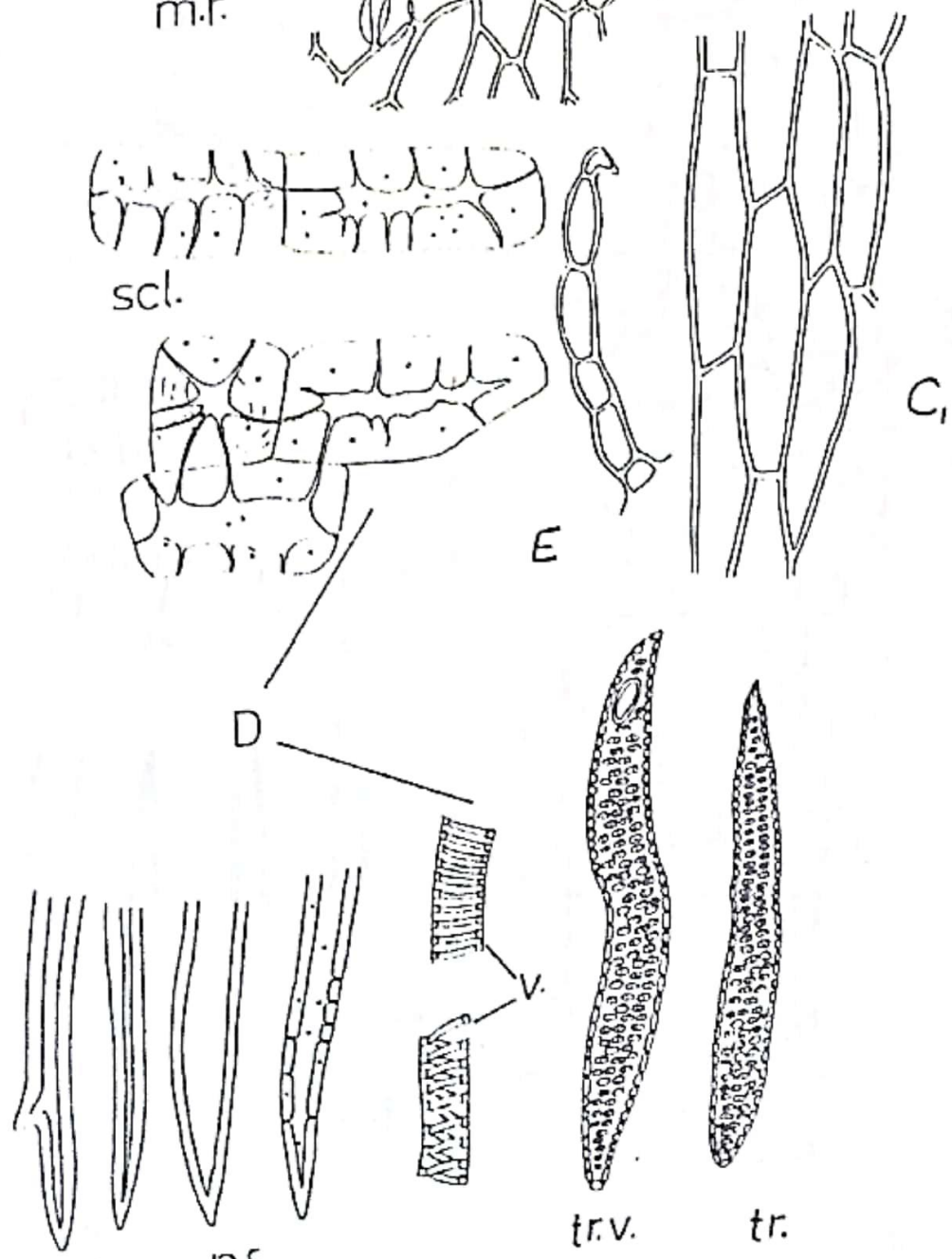
W.F. P.F.

(All $\times 282$ except $E \times 246)$

(Fig. 6) : The stem : $\quad$ the risge. C. Fipidermal rells of the stem. $C_{1}$. Tipiriermal cells of the stem on the the stem.

1). Isolared elements from the sericyclic fiber; Scl., sclerides; tr., tracheids; tr.v, tracheidal

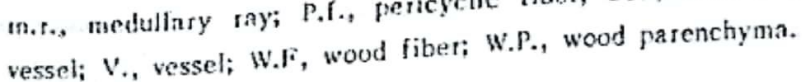




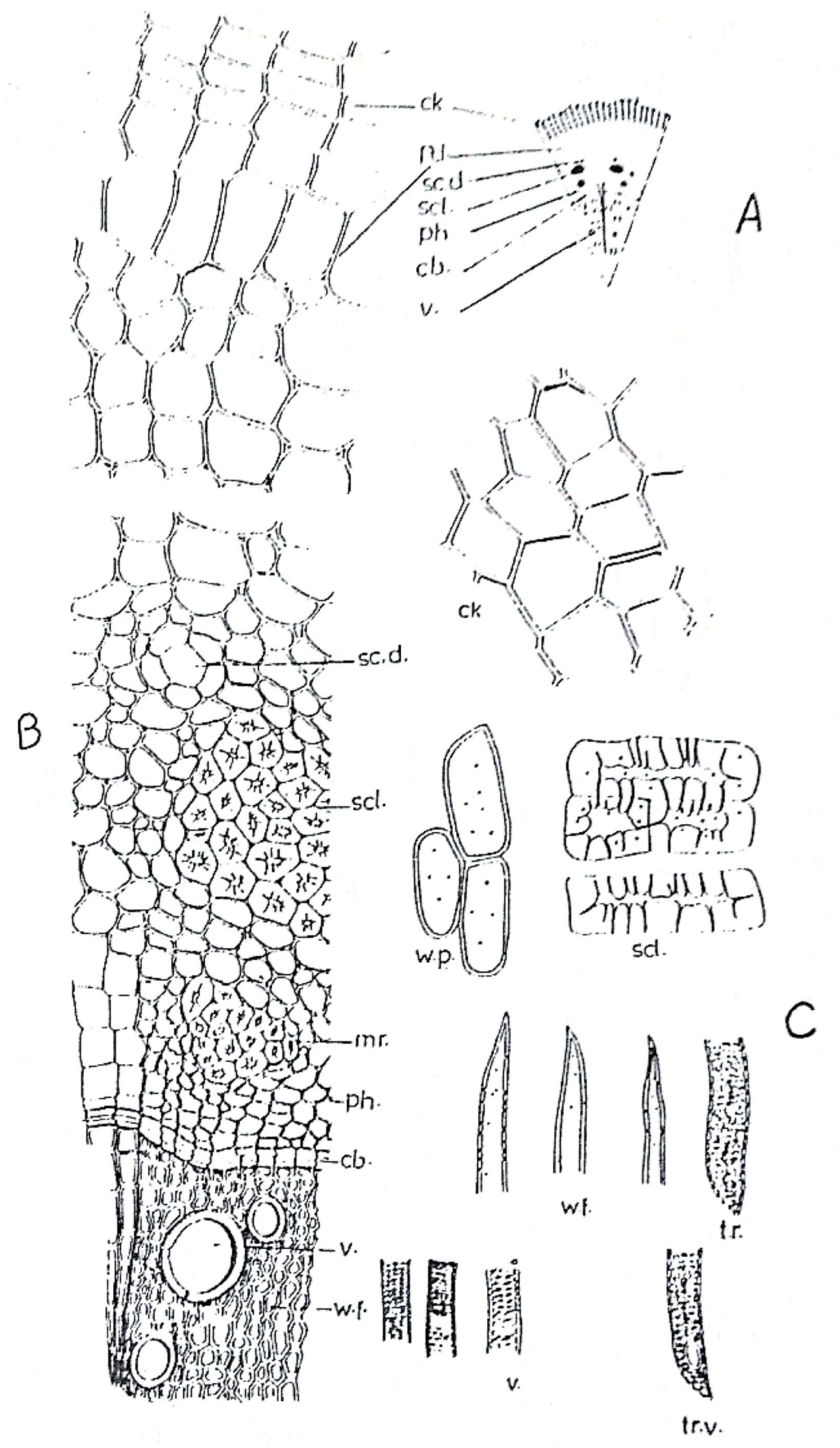

(Fig. 7): The root: $(\Lambda 11 \times 193.6$ except $\wedge \times 17.6)$

A. Diagrammatic transverse Section of old root.

B. Detailed transverse Section of old root.

c. Isolated elements from root..

Ch.,cambium; CK., cork; m.r., medullary ray; pd., phelloderm; ph., phloem; Sc.d., Secretory W.p., wood parenchyma. 


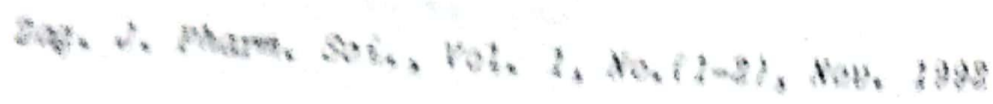

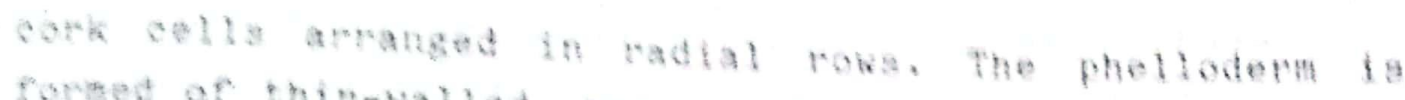

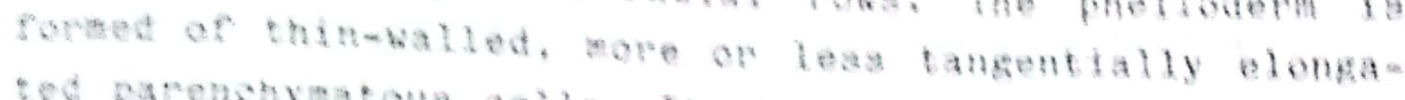

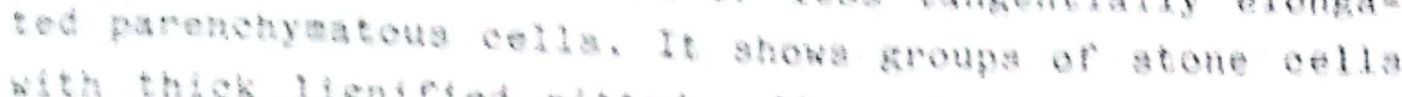

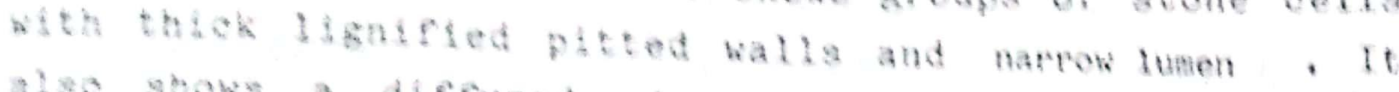
alsh shows a difrused ring of sohtzogenous sechotory duets.

The vascular tissue consists of an outor phloem and an inmer ring of xyles hith cambium th between. Phloem Is formed of thin-kalled, soft cellulosio olementa. Cambtum is comed of several roks of radially arranged meristematic cells. Xytem is lignified with tetrarch primary xylem at the centre. It is formed of ammular. spimal and oval bordered pitted vessels, 21 to 51 u in diameter, Tracheids and tracheidal vessels are few with lignifted walls showing oval bordered pits and acute to accuminate apices. Tracheids measure, $227-297$ u in length and $23-28$ u in diameter. Tracheidal vessels measure $345-479$ u in length and $15-23$ u in diameter. Wood parenchyma have thin pitted lignified walls. Meduallry rays; are uni-to trisseriate being lignified with pitted walls in xylem region.

\section{CONCLUSION}

As a result of this study one can conclude the following characteristic reatures.

1. The plant is herbaceous with $7-12$ radical leaves and two types of cauline leaves. The plant flowering from March to May carrying both terminal and axillary large rose red capitula with an involucre scale showing white fringes and terminal long, yellow spines.

2. The leaf shows an isobilateral structure, three collateral vascular bundle, each consists of radi- 
ated $x y l e m$ and phloem surrounded by two arcs crescent-shaped pericyclic fibres above and beneath.

3. The stem is almost circular in outline with 6-9 ridges. The transverse section showing an outer epidermis followed by narrow cortex then endodermis enclosing a ring of vascular tissue surrounding a wide pith.

4. Stomata of anomocytic and anisocytic types are present in the epidermis of the leaves and stem. Trichomes of non-glandular uniseriate and multicellular are numerous in leaves being few in stem.

5. The young root is tetrach.

6. The pericycle of the leaves and stem are formed of lignified sclerenchymatous fibres with thick pitted walls and acute, subacute or forked apices.

7. The xylem vessels in root, stem and leaves shows annular, spiral, reticulate or boardered pitted thickening, tracheids and tracheidal vessels.

8. The leaves, stem and root are completely free of starch granules and calcium oxalate crystals.

\section{REFERENCES}

1. Tackholm, v. "Students Flora of Egypt". 2nd Ed. Cairo Univ. Press, 538-43 (1974).

2. Watt, J.M. and Breyer M.G., "Medicinal and Poisonous plant of Southern and Eastern Africa". Livingstone Ltd. Edinburgh and London 2nd Ed., 210-11 (1962).

3. Ahmed, Z.F.; Rizk, A.M.; and Hammouda, F.M.; Wygloszone Symp. 1970, 20-3 (Pub. 1972).

4. Gonzalez, A.G.; Darias, V.; Alonso, G. and Eștevez, E.; Planta Med., 40 (2), 179-84 (1980). 
Zag. J. Pharm. Sci., Vol. 1, No. (1-2), Nov. 1992

5. Sarg, T.; El-Dahmy, S.; El-Domiaty, M. and El-Shazly, A; Sci. Pharm., 57, 63-67 (1989).

6. Sarg, T.M.; El-Domiaty, M.M.; El-Dahmy,S. 1; Ateya, A.M. and El-Shazly, A.M.; Alex. J. Pharm. Sci. 1993, in Press.

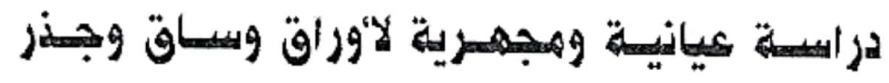

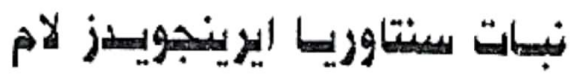

$$
\begin{aligned}
& \text { طه هصطفى سرجة - عبد المنعم هـمد عطية } \\
& \text { سميح إبراهيمم التهمسى - هاهر هـمد الدهياطى لهري }
\end{aligned}
$$

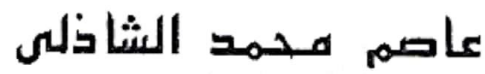

$$
\begin{aligned}
& \text { قسم العقاقيـر- كلية الصيدلة - جامعة الزقازيق }
\end{aligned}
$$

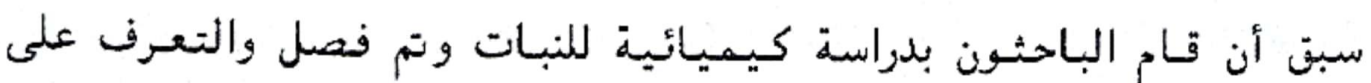

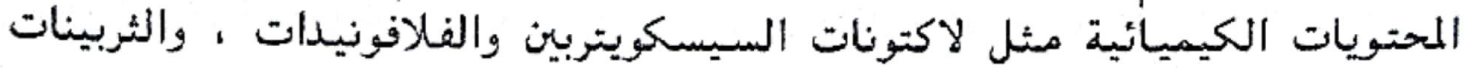

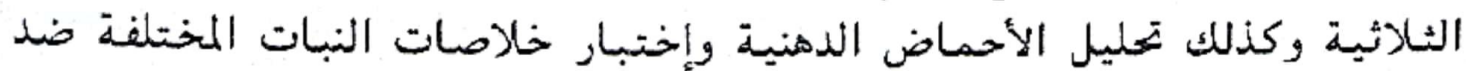

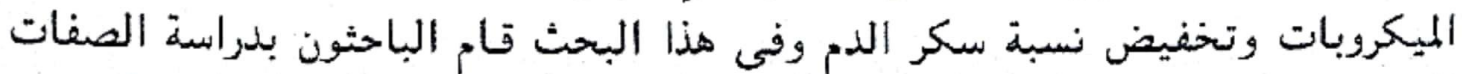

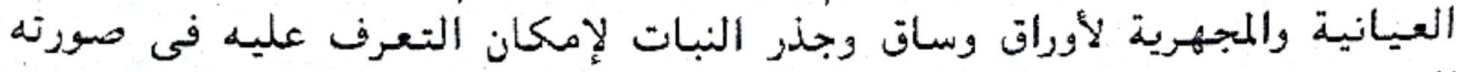
الصحيحة وعلمى هيئة مسحوق لأوراق وسان 